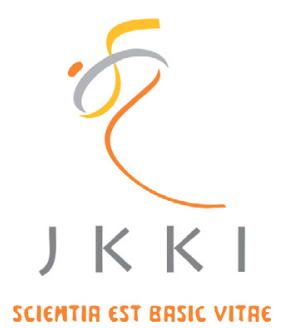

Jurnal Kedokteran dan Kesehatan Indonesia

Indonesian Journal of Medicine and Health

Journal homepage : www.journal.uii.ac.id/index.php/JKKI

\title{
Characterization, formulation and evaluation of glibenclamide with $\beta$-cyclodextrin inclusion complexes tablets
}

\author{
Yandi Syukri*1 ${ }^{*}$ Farida Ulfa ${ }^{1}$, Asih Lestari ${ }^{1}$, Lelita Ayu Saputri ${ }^{1}$, Rochmy Istikharah ${ }^{1}$, Aris Perdana Kusu- \\ $\mathrm{ma}^{1}$ \\ ${ }^{1}$ Department of Pharmacy, Faculty of Mathematics and Natural Sciences, Universitas Islam Indonesia, Yogyakarta, \\ Indonesia
}

Original Article

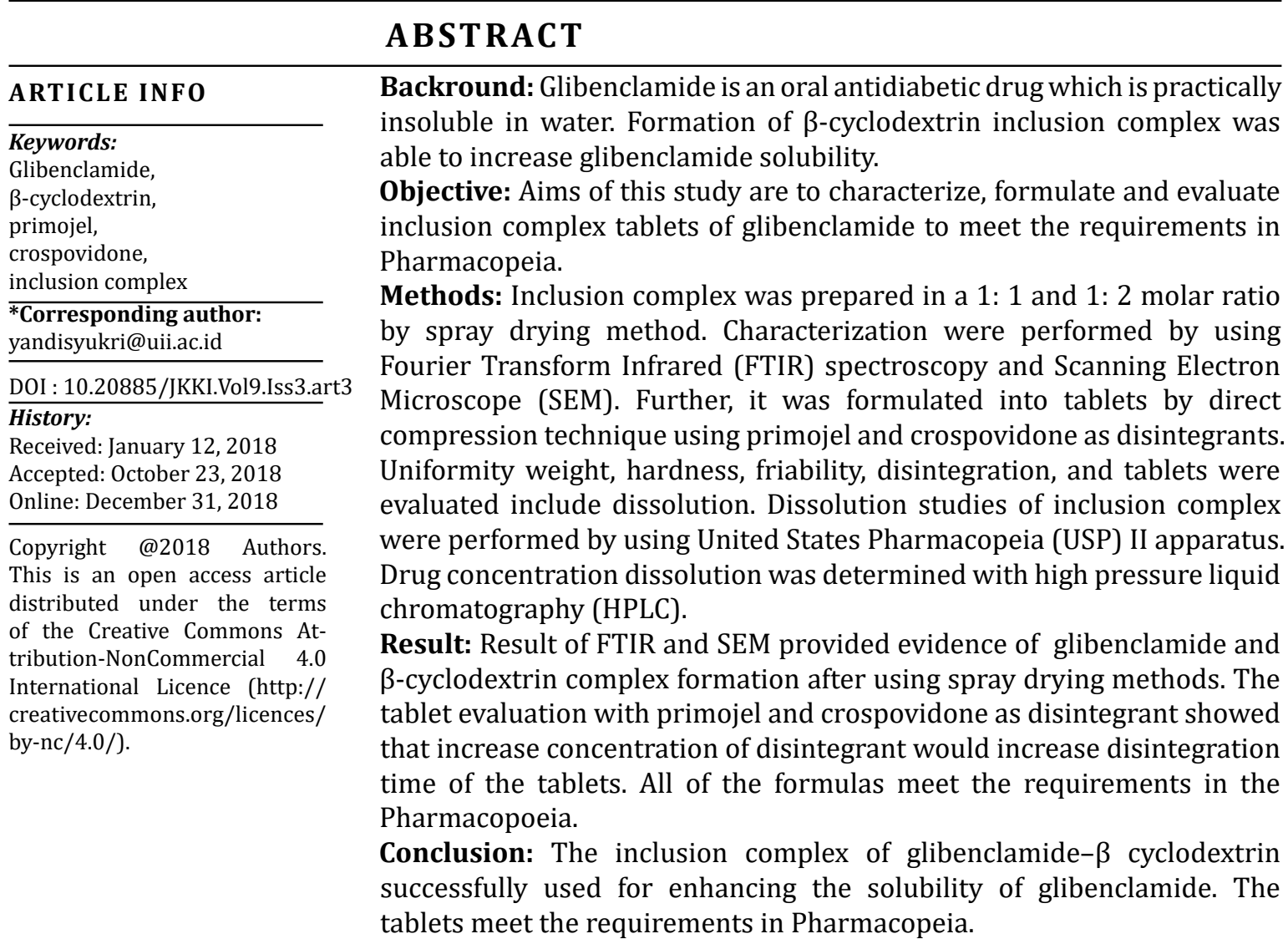

Latar Belakang: Glibenklamid merupakan obat antidiabetes oralyang sukar larut dalam air. Pembentukan komplek inklusi dengan $\beta$-siklodekstrin diharapkan mampu meningkatkan kelarutan glibenklamid.

Tujuan Penelitian: Penelitian ini bertujuan untuk mengkarakterisasi, memformulasi dan mengevaluasi tablet hasil komplek inklusi glibenklamid supaya memenuhi persyaratan Farmakope.

Metode: Komplek inklusi dibuat dengan perbandingan rasio molar glibenklamid dan $\beta$-siklodekstrin 1 : 1 dan 1 : 2 dengan menggunakan metode spray drying. Hasil komplek inklusi dikarakterisasi meliputi spektroskopi FTIR dan SEM. Selanjutnya kompleks tersebut diformulasi menjadi tablet dengan teknik kempa langsung menggunakan primojel dan crospovidon sebagai disintegran. Tablet yang dihasilkan dievaluasi keseragaman bobot, kekerasan, kerapuhan, waktu hancur dan disolusi. Uji disolusi tablet hasil 
komplek inklusi dilakukan dengan mengunakan alat uji disousi United States Pharmacopeia (USP) tipe II dan kadar obat terdisolusi ditetapkan menggunakan Kromatografi Cair kinerja Tinggi (KCKT).

Hasil: Hasil dari FTIR dan SEM menunjukkan bahwa terjadinya pembentukan komplek antara glibenklamid dan $\beta$-silodekstrin setelah dibuat dengan metode spray drying. Hasil evaluasi tablet komplek inklusi glibenklamid dan $\beta$-silodekstrin dengan primojel dan crospovidon sebagai disintegran menunjukkan bahwa dengan meningkatnya kadar disintegran akan meningkatkan waktu hancur tablet. Semua formula memenuhi persyaratan dalam farmakope.

Kesimpulan: Komplek inklusi glibenklamid dan $\beta$-silodekstrin telah berhasil meningkatkan kelarutan dari glibenklamid dan tablet memenuhi persyaratan farmakope.

\section{INTRODUCTION}

Drug solubility is one of an important factors for determine amount and rate of drugs absorption especially in gastrointestinal tract. ${ }^{1}$ Drugs with limited solubility in water exhibit low absorption and bioavailability. This condition are due to drug dissolution rates in the gastrointestinal tract. Many methods have been done to improve dissolution characteristics of poorly water-soluble drugs such as reducing particle size, crystal modification, complex with cyclodextrins and self-emulsification. ${ }^{2}$

Cyclodextrins have been widely used in designing pharmaceutical formulations of dissolve water-insoluble drugs. Several methods have been reported for the formation of drug inclusion complexes with cyclodextrins such as freeze drying, spray drying, co-precipitation, kneading and extrusion. Each of these methods gives different results in particle size,number of complex formations and the amorphous levels of the final product. ${ }^{3}$ Formation drugs complexes with cyclodextrin is a prospecting method to be develop because of its ability to increase solubility, wettability, dissolution and bioavailability of orally administered drugs. ${ }^{4}$ Recent publications reported that cyclodextrins improved solubility and dissolution of itraconazole, curcumin, repaglanid, mirisetin, and glimepiride..$^{5-9}$
Spray drying method is one method that has been widely used to evaporate solvent for the formation of complex inclusion of poorly water-soluble drugs with $\beta$-cyclodextrin. The results of aripiprazole- $\beta$-cyclodextrin inclusion complex prepared by spray drying technique showed that this techniques could increase solubility and dissolution rate of aripiprazole. ${ }^{10}$ Spray drying technique is also reported as one of the successful methods applied for solvent evaporation of complex inclusion in quercetin, indomethacin and corticosteroid. ${ }^{11-13}$

Glibenclamide is a hypoglycemic compound recommended for type 2 diabetes mellitus. Based on the biopharmaceutical classification system, glibenclamide is classified into class II that has low solubility and a high permeability to cross the gastrointestinal mucosa. ${ }^{14}$ Therefore, efforts should be made to improve glibenclamide dissolution to obtain optimal bioavailability. Some of the approaches that have been taken to enhance glibenclamide dissolution include solid dispersion, permeation enhancer and selfemulsification. ${ }^{15}$

Aims of this study are to characterize, formulate and evaluate inclusion complex tablets of glibenclamide to meet the requirements in Pharmacopeia.

The following inclusion complexes are formulated into tablets with direct compression techniques using primojel and crospovidone as the disintegrant to attempt the increase of glibenclamide dissolution prepared into tablets.

\section{METHODS}

\section{Materials}

The ingredients used in this study were glibenclamide (PT Phapros), $\beta$-cyclodextrin (PT Signa Husada), crospovidone (PT Dexa Medika) and all excipients such as primojel, aerosil, avicel PH-102, and magnesium stearate were obtained from the Pharmacy Laboratory of Islamic University of Indonesia. All ingredients used have a pharmaceutical grade. 
Preparation of glibenclamide inclusion complex with $\beta$ - cyclodextrin

The inclusion complex was conducted by spray drying method using a mini spray dryer (B290 Buchi). Glibenclamide with $\beta$-cyclodextrin with 1: 1 and 1: 2 molar ratio were added in ethanol and stirred until dissolved. The solution was powdered using a spray dryer at an inlet temperature of $1200 \mathrm{C}$ until the powder was produced.

\section{Fourier transform infrared (FTIR) spectroscopy}

Fourier transform infrared spectra (Nicolet Avatar 360) were used for the study of molecular samples at wavelengths of 400$4000 \mathrm{~cm}^{-1}$. Glibenclamide, $\beta$-cyclodextrin and glibenclamide inclusion complex- $\beta$-cyclodextrin were powdered with potassium bromide $(\mathrm{KBr}$ $1: 150)$ and compressed into transparent pellets for analyses.

\section{Scanning electron microscopy (SEM)}

Scanning electron microscopy (Jeol JSTM T300 model) was used to analyze the formation of glibenclamide, $\beta$-cyclodextrin and glibenclamide$\beta$-cyclodextrin inclusion complexes. Each sample was coated with gold using a fine coater. The sample was glued to the specimen stage and observations are conducted.

\section{Preparation of complex inclusions tablets}

Tablets of glibenclamide inclusion complex$\beta$-cyclodextrin were prepared by directcompression techniques containing $5 \mathrm{mg}$ of glibenclamide each tablet. The inclusion

Table 1. The formulas for preparing glibenclamide inclusion complex tablets with $\beta$-cyclodextrin (1: 2M) with primojel and crospovidone as a disintegrant (weight for one tablet)

\begin{tabular}{lrrrrrrrrrr}
\hline Materials & F1 & F2 & F3 & F4 & F5 & F6 & F7 & F8 & F9 & F10 \\
\hline $\begin{array}{l}\text { Glibenclamide and } \\
\text {--cyclodextrin inclusion } \\
\text { complexes (mg) }\end{array}$ & 30.5 & 30.5 & 30.5 & 30.5 & 30.5 & 30.5 & 30.5 & 30.5 & 30.5 & 30.5 \\
$\begin{array}{l}\text { Primojel (mg) } \\
\text { Crospovidone (mg) }\end{array}$ & 2.0 & 3.5 & 5.0 & 6.5 & 8.0 & & & & & \\
Avicel PH 102 (mg) & 65.5 & 64.0 & 62.5 & 61.0 & 59.5 & 65.0 & 64.25 & 63.5 & 62.75 & 62.0 \\
Magnesium stearate & 1.0 & 1.0 & 1.0 & 1.0 & 1.0 & 1.0 & 1.0 & 1.0 & 1.0 & 1.0 \\
(mg) & 1.0 & 1.0 & 1.0 & 1.0 & 1.0 & 1.0 & 1.0 & 1.0 & 1.0 & 1.0 \\
Aerosil (mg) & 100 & 100 & 100 & 100 & 100 & 100 & 100 & 100 & 100 & 100 \\
Total quantity (mg) & & & & & & & & & & \\
\hline
\end{tabular}

complex and all excipients were mixed until homogeneous and subsequently compressed by using a single punch tablet machine (Korsh EK 0 ). The compositions of each formula is shown in Table 1.

\section{Tablet evaluation}

The weight variation was determined by weighing 20 tablets and calculating the average weight of each tablet, following the requirements of Pharmacopeia. ${ }^{16}$ The hardness test was performed ten times using the hardness tester (Vanguard YD-2). Tablet was placed on the tool in a horizontal position and the instrument was calibrated to a position of 0.00 . The device was run until the tablet breaks, then read the scale shown on the apparatus. ${ }^{17}$ The friability was determined by weighing 20 tablets and put into a friability tester (Erweka TA 200) that rotates for 4 minutes at $25 \mathrm{rpm}$. Next weighed tablet weight to obtain percent friability. ${ }^{17}$ The disintegration time was performed for six tablets in each 
formula and determined by the disintegration tester (Erweka ZT 502) containing distilled water at $37 \pm 0.50 \mathrm{C}$. Then the time was recorded until all the tablets were pass-through screen at the bottom of the flask in the equipment. ${ }^{18}$

\section{Content uniformity}

Twenty tablets were weighed and powdered.
Then, weighed powder equivalent to $5 \mathrm{mg}$ of glibenclamide and mixed with $2 \mathrm{ml}$ of distilled water and $20 \mathrm{ml}$ of methanol. After that, mixture was filtered and the glibenclamide content was determined using HPLC (Waters e-265). ${ }^{18}$

\section{Dissolution In Vitro}

The test was using dissolution test apparatus

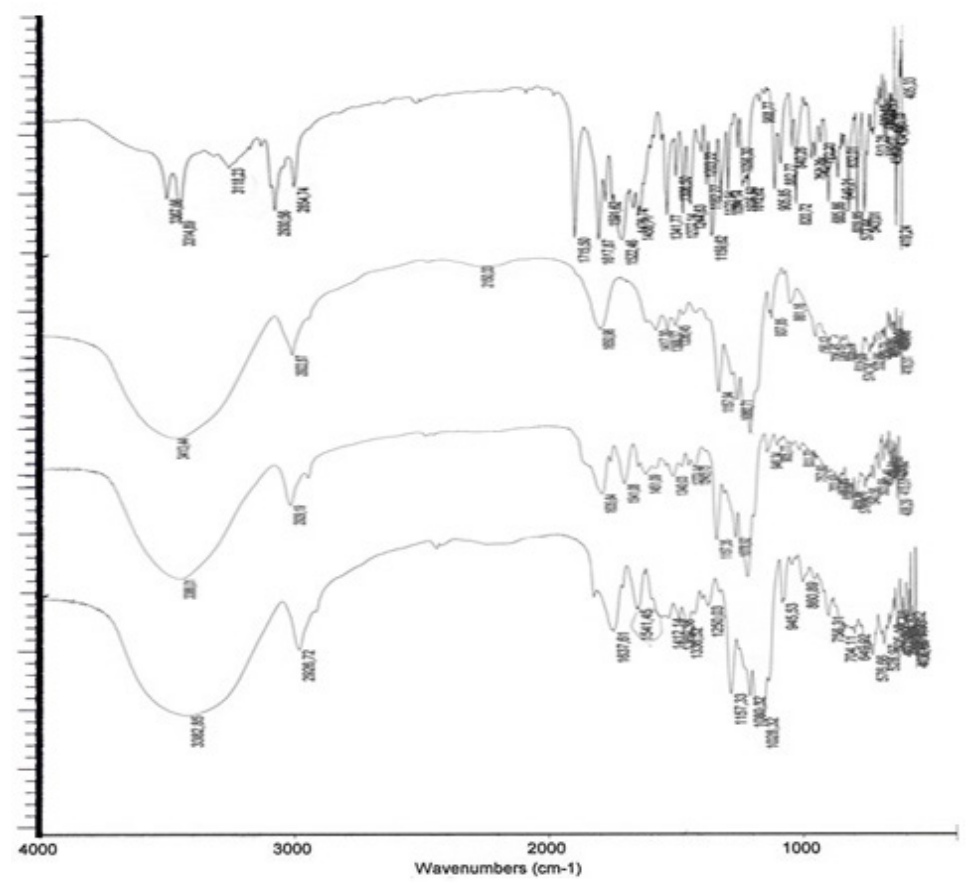

Figure 1. FTIR spectra of glibenclamide (a), $\beta$-cyclodextrin (b), inclusion complex glibenclamide- $\beta$-cyclodextrin $1: 1$ (c), and glibenclamide- $\beta$ cyclodextrin inclusion complex 1: 2

(Erweka DT 708) type 2. The tablet was placed into a dissolution device containing $900 \mathrm{~mL}$ dissolution medium at $37 \pm 0.50 \mathrm{C}$ with rotation speed of $100 \mathrm{rpm}$ for $45 \mathrm{~min}$. Ten $\mathrm{mL}$ sample was taken at 45 minutes. Glibenclamide content level was determined using the HPLC (Waters e-265) at $225 \mathrm{~nm}$ wavelength. ${ }^{18}$

\section{RESULTS}

\section{Fourier transform infrared (FTIR)} spectroscopy.

Result of inclusion complexes of glibenclamide- $\beta$-cyclodextrin $1: 1$ and the inclusion glibenclamide- $\beta$-cyclodextrin $1: 2$. FTIR spectra can be presented in the Figure 1.
Infra red (IR) spectroscopy test aimed to determine interaction of inclusion complexes between glibenclamide and $\beta$-cyclodextrin through the occurrence of functional group band shifts on the result of inclusion complex of glibenclamide- $\beta$-cyclodextrin. The results of the infrared spectra were analyzed by focusing on areas above $1500 \mathrm{~cm}^{-1}$ or above the fingerprint regions possessed by glibenclamide in $\beta$-cyclodextrin complexes to describe the possibility of interaction.

\section{Scanning electron microscopy (SEM).}

Scanning electron microscopy analysis was performed on pure glibenclamide, $\beta$-cyclodextrin 
and inclusion complex of glibenclamide- $\beta$ cyclodextrin (1: 1 and 1:2 inclusion complex). SEM results were presebted in Figure 2. SEM was shown to describe the surface morphology of glibenclamide, $\beta$-cyclodextrin and both complex formulas inclusion of glibenclamide- $\beta$-cyclodextrin. SEM as Figure 2 showed that there was a change of form between pure glibenclamide, glibenclamide- $\beta$-cyclodextrin 1: 1 inclusion complex and glibenclamide- $\beta$ cyclodextrin 1: 2 inclusion complex.
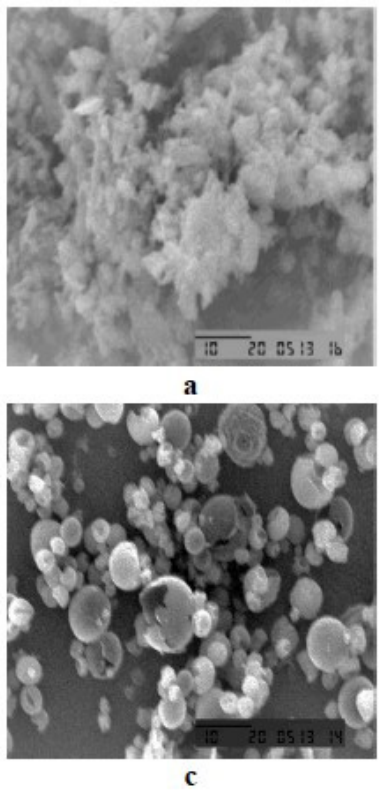

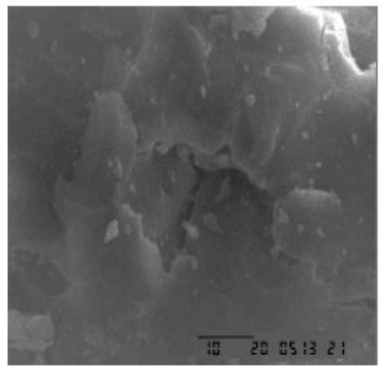

b

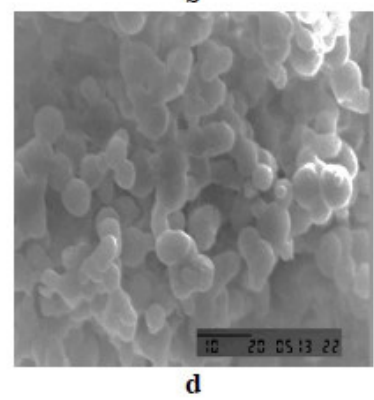

Figure 2. Scanning electron microscopy of glibenclamide (a), $\beta$-cyclodextrin (b), inclusion complex glibenclamide$\beta$-cyclodextrin 1:1 (c), inclusion complex glibenclamide$\beta$-cyclodextrin 1: 2 (d).

Tablet evaluation

Result of weight variation, hardness, friability and disintegration time can be illustrated in Table 2.

Table 2. The evaluation results of glibenclamide - $\beta$ cyclodextrin inclusion complex tablets 1: $2 \mathrm{M}$. The variations of the averages are shown as SD

\begin{tabular}{ccccc}
\hline Formulas & $\begin{array}{c}\text { Average weight } \\
\text { (mg) }\end{array}$ & $\begin{array}{c}\text { Hardness } \\
\text { (kg) }\end{array}$ & $\begin{array}{c}\text { Friability } \\
\text { (\%) }\end{array}$ & $\begin{array}{c}\text { Disintegration time } \\
\text { (sec) }\end{array}$ \\
\hline F1 & $101.90 \pm 1.26$ & $6.41 \pm 0.35$ & $0.25 \pm 0.08$ & $100.67 \pm 2.00$ \\
F2 & $106.65 \pm 0.71$ & $6.03 \pm 0.45$ & $0.17 \pm 0.18$ & $90.00 \pm 1.00$ \\
F3 & $97.00 \pm 1.05$ & $5.30 \pm 0.30$ & $0.10 \pm 005$ & $71.67 \pm 1.52$ \\
F4 & $99.50 \pm 1.08$ & $6.03 \pm 0.40$ & $0.07 \pm 0.02$ & $56.00 \pm 1.00$ \\
F5 & $98.95 \pm 1.03$ & $4.88 \pm 1.82$ & $0.28 \pm 0.11$ & $38.00 \pm 1.73$ \\
F6 & $103.25 \pm 1.42$ & $7.43 \pm 0.30$ & $0.01 \pm 0.00$ & $444.00 \pm 3.11$ \\
F7 & $103.00 \pm 1.69$ & $6.92 \pm 1.69$ & $0.02 \pm 0.00$ & $336.60 \pm 2.67$ \\
F8 & $103.25 \pm 1.89$ & $6.41 \pm 1.11$ & $0.03 \pm 0.00$ & $277.80 \pm 2.61$ \\
F9 & $103.00 \pm 1.17$ & $6.01 \pm 0.78$ & $0.04 \pm 0.00$ & $156.60 \pm 2.35$ \\
F10 & $103.05 \pm 1.90$ & $5.28 \pm 1.07$ & $0.05 \pm 0.02$ & $144.00 \pm 2.11$ \\
\hline
\end{tabular}




\section{Content uniformity}

Result of the determination of active substance in the inclusion complex tablets were shown in Table 3.

\section{In vitro dissolution}

Table 4 presented results of in vitro dissolution test at minute 45 (Q45).

Table 3. Content uniformity of glibenclamide- $\beta$ cyclodextrin inclusion complex tablets $(n=3)$. The variations of the averages are shown as SD

\begin{tabular}{cc}
\hline Formulas & Content active substance (\%) \\
\hline F1 & $103.21 \pm 0.09$ \\
F2 & $96.08 \pm 1.36$ \\
F3 & $101.56 \pm 0.89$ \\
F4 & $99.42 \pm 0.72$ \\
F5 & $96.38 \pm 0.09$ \\
F6 & $95.58 \pm 0.21$ \\
F7 & $82.21 \pm 0.24$ \\
F8 & $83.58 \pm 0.49$ \\
F9 & $85.94 \pm 0.72$ \\
F10 & $87.61 \pm 0.49$ \\
\hline
\end{tabular}

Table 4. In vitro dissolution test at minute 45 (Q45) of glibenclamide - $\beta$ cyclodextrin inclusion complex tablets $(n=3)$. The variations of the averages are shown as SD.

\begin{tabular}{cc}
\hline Formulas & $\begin{array}{c}\text { Dissolution at minute 45 } \\
(\mathbf{Q = 4 5})\end{array}$ \\
\hline F1 & $80.02 \pm 1.04$ \\
F2 & $83.50 \pm 1.38$ \\
F3 & $85.94 \pm 0.49$ \\
F4 & $87.78 \pm 1.23$ \\
F5 & $91.88 \pm 1.71$ \\
F6 & $80.66 \pm 0.85$ \\
F7 & $82.21 \pm 0.24$ \\
F8 & $83.58 \pm 0.49$ \\
F9 & $85.94 \pm 0.72$ \\
F10 & $87.61 \pm 0.49$ \\
\hline
\end{tabular}

\section{DISCUSSIONS}

Infrared spectra as shown in Figure 1 showed that glibenclamide had a specific absorption at
$3300-3370 \mathrm{~cm}^{-1}$ (NH stretching) and $2900 \mathrm{~cm}^{-1}$ (-CH stretching) wavelength. Wavelength at 1710 $\mathrm{cm}-1$ indicate $\mathrm{C}=0$ bonds. Strong absorption 
at $1520 \mathrm{~cm}-1$ indicated the presence of $\mathrm{C}=\mathrm{C}$ bonds. Wavelength at $1340 \mathrm{~cm}-1$ indicate the presence of $\mathrm{CO}$ and at $1160 \mathrm{~cm}^{-1}$ indicate the peak in $\mathrm{SO}_{2} \cdot{ }^{19}$ The $\beta$-cyclodextrin spectra showed that $\beta$-cyclodextrin had a widened range at 3413 $\mathrm{cm}^{-1}$ wavelength which are spectrum of $\mathrm{OH}$. The CH bond was seen in the area of $2922 \mathrm{~cm}^{-1}$ and the C-C bond arose in the area of $1157 \mathrm{~cm}^{-}$ ${ }^{1}$. In the inclusion, complex spectra appeared an $\mathrm{O}-\mathrm{H}$ spectrum at the $3386 \mathrm{~cm}^{-1}$ and 3383 $\mathrm{cm}^{-1}$ wavelength in the 1: 1 and 1: 2 inclusion complexes. The interaction of hydrogen bond formation in the inclusion complex undergoes a ribbon shift which can be seen in the absorption of $\mathrm{O}-\mathrm{H}$ group to the right or toward the lower spectra.

A slight shift in the above-infrared spectra was due to an interaction between glibenclamide and $\beta$-cyclodextrin with weak bonds. The complex was formed at the time of recrystallization of glibenclamide and $\beta$-cyclodextrin that coincide with the solvent evaporation by spray drying process. $\beta$-cyclodextrin enveloped the glibenclamide at the time of recrystallization, so that in the visible spectra $\beta$-cyclodextrin is more apparent than glibenclamide. The FTIR spectra of inclusion complexes would change because of bending loss and vibrating peaks of the molecule after complexation formation. The complexes did not show additional peaks. It can be explained by the presence of non-covalent interactions. ${ }^{20,21}$

The SEM images showed that pure glibenclamide exhibited a small collection of crystals in various forms, whereas glibenclamide$\beta$-cyclodextrin inclusion complex exhibited an amorphous structure. Inclusion complex showed that $\beta$-cyclodextrin envelops glibenclamide. This event occurred at the time of recrystallization by solvent evaporation using spray drying. The inclusion complex happens when glibenclamide enters the $\beta$-cyclodextrin hydrophobic cavityresultingthe increased dissolution of glibenclamide. This can be explained that a new complex of $\beta$-cyclodextrin and glimepiride are formed. Previous studies shows thatformation of solid inclusion complex between $\beta$-cyclodextrin and guest molecules was closely correlated with the varied crystal shapes. ${ }^{22}$

Table 2 showed that all formulas meet the requirements of weight variation and mechanical properties (hardness and friability). The hardness test indicate a good mechanical strength and the friability less than $1 \%$ indicate that the tablet had a good resistance to external forces like shock and abrasion. The data were fullfil the requirements in the compendial acceptable range. ${ }^{23}$

Results of the disintegration time tablets indicate that all tablets meet the requirements (less than 15 minutes or 900 seconds). Increase concentration of primojel and crospovidone will increase the disintegration time of tablets. Primojel can absorb water quickly followed by their ability to expand well in contact with water. These expanding particles cause the tablet to break, so it can contribute to speed up tablet's disintegration time. Crospovidone as a tablet disintegrant had a good capillarity and swelling mechanisms. Water will absorb into the tablet and produce tablet expand. The tablet composing particles will be pressed until the tablet breaks. The disintegration mechanism tablet contain crospovidone as the super disintegrant showed by an initial swelling followed into fine particles. During wetting, the crospovidone in the tablet lost it's post compression deformity in the form of swelling. ${ }^{23}$ This reseach shows that primojel has better disintegrant ability than crospovidone.

The content and uniformity of oral solid dosage forms are invariably defined as drug product critical quality attributes. This can impact the safety and efficacy for the patient. ${ }^{24}$ Concentration of the active substance is one of the requirements that must be fulfilled by a proper tablet preparation. The proper amount of active substance is essential for efficacy and it is crucial to meet the requirements of tablet. Theoretically,glibenclamide tablets contain 5 mg of active ingredient. The requirement of 
glibenclamide content in a tablet preparation according to British Pharmacopoeia is to provide not less than $90 \%$ and not more than $110 \%$ of the amount indicated on label..$^{25}$ This research showed that all formulas meet the requirements, i.e., glibenclamide tablets containing not less than $90 \%$ and not more than $110 \%$ of those listed. Based on these results it can be said that the tablet complex are good enough because it deals with right weight uniformity as well.

Dissolution test was carried out to determine the amount of drug dissolution in an appropriate medium. The results of dissolution data establish with $Q$ value which describes the percentage of drugs released at a specific minute. The United States Pharmacopeia (USP) stated that the dissolution ( $Q$ value) was not less than $70 \%$ at the 45 minutes. The dissolution test as shown in this research showed that all formulas meet the percent requirements of dissolution glibenclamide tablet at 45 minutes, i.e., not less than $70 \%$ of those listed. The ability of dissolution will be related to the disintegration capability of the tablet. If the tablets disintegration rapidly, a highernumber of dissolved drugs can be found. This can be seen in formula $V$ which has a faster disintegration time than other formulas.

\section{CONCLUSION}

The inclusion complex of glibenclamide- $\beta$ cyclodextrin successfully used for enhancing the solubility of glibenclamide. The tablets meet the requirements in Pharmacopeia. All tablets of inclusion complex produce good quality tablets and meet the requirements listed on pharmacopeia

\section{ACKNOWLEDGMENT}

The authors would like to thank the Pharmacy Laboratory of the Islamic University of Indonesia for the facilities and funding of this research.

\section{Conflict of interest}

The authors declare that they have no conflict of interest.

\section{REFERENCES}

1. Elkordy AA, Jatto A, Essa E. In situ controlled crystallization as a tool to improve the dissolution of Glibenclamide. International Journal of Pharmaceutics. 2012 ;428(1-2):11820. DOI: 10.1016/j.ijpharm.2012.02.046

2. Kawabata Y, Wada K, Nakatani M, Yamada S, Onoue S. Formulation design for poorly water-soluble drugs based on biopharmaceutics classification system: Basic approaches and practical applications. International Journal of Pharmaceutics. 2011 ;420(1):110.DOI: 10.1016/j.ijpharm.2011.08.032

3. Khadka P, Ro J, Kim H, Kim I, Kim JT, Kim H, et al. Pharmaceutical particle technologies: An approach to improve drug solubility, dissolution and bioavailability. Asian Journal of Pharmaceutical Science. 2014 ;9(6):30416.DOI:https://doi.org/10.1016/j. ajps.2014.05.005

4. Shanmuga Priya A, Sivakamavalli J, Vaseeharan B, Stalin T. Improvement on dissolution rate of inclusion complex of Rifabutin drug with $\beta$-cyclodextrin. International Journal Biological Macromolecules. 2013 ;62:47280.DOI:10.1016/j.ijbiomac.2013.09.006

5. Taupitz T, Dressman JB, Buchanan CM, Klein S. Cyclodextrin-water soluble polymer ternary complexes enhance the solubility and dissolution behaviour of poorly soluble drugs. Case example: Itraconazole. European Journalof Pharmacetics and Biopharmaceutics. 2013 ;83(3):378-87.DOI: 10.1016/j.ejpb.2012.11.003

6. Michel D, Chitanda JM, Balogh R, Yang P, Singh J, Das U, et al. Design and evaluation of cyclodextrin-based delivery systems to incorporate poorly soluble curcumin analogs for the treatment of melanoma. European Journal of Pharmaceutics and Biopharmaceutics. 2012 ;81(3):548-56.DOI: 10.1016/j.ejpb.2012.03.016

7. Liu M, Cao W, Sun Y, He Z. Preparation, characterization and in vivo evaluation of formulation of repaglinide with hydroxypropyl- $\beta$-cyclodextrin. International Journal of Pharmaceutics. 2014;477(1-2):159-66. 
DOI: 10.1016/j.ijpharm.2014.10.038

8. Yao Y, Xie Y, Hong C, Li G, Shen H, Ji G. Development of a myricetin/hydroxypropyl- $\beta$-cyclodextrin inclusion complex: Preparation, characterization, and evaluation. Carbohydrate Polymers. 2014;110:329-37.DOI: 10.1016/j.carbpol.2014.04.006

9. Syukri Y, Fernenda L, Utami FR, Qiftayati I, Kusuma AP, Istikaharah R. Preperation and Characterization of B-Cyclodextrin Inclusion Complexes Oral Tablets Containing Poorly Water Soluble Glimipiride Using Freeze Drying Method. Indonesian Journal of Pharmacy. 2015 ;26(2):71.DOI: http://dx.doi.org/10.14499/indonesianjpharm26iss2pp71

10. Mihajlovic T, Kachrimanis K, Graovac A, Djuric Z, Ibric S. Improvement of Aripiprazole Solubility by Complexation with (2-Hydroxy)propyl- $\beta$-cyclodextrin Using Spray Drying Technique. AAPS PharmSciTech. 2012 ;13(2):623-31.DOI: 10.1208/ s12249-012-9786-3

11. Borghetti GS, Lula IS, Sinisterra RD, Bassani VL. Quercetin/ $\beta$-Cyclodextrin Solid Complexes Prepared in Aqueous Solution Followed by Spray-drying or by Physical Mixture. AAPS PharmSciTech. 2009;10(1):235-42.DOI: 10.1208/s12249009-9196-3

12. Rudrangi SRS, Bhomia R, Trivedi V, Vine GJ, Mitchell JC, Alexander BD, et al. Influence of the preparation method on the physicochemical properties of indomethacin and methyl- $\beta$-cyclodextrin complexes. International Journal of Pharmaceutics. 2015 ;479(2):381-90.DOI:10.1016/j.ijpharm.2015.01.010

13. Cabral-Marques H, Almeida R. Optimisation of spray-drying process variables for dry powder inhalation (DPI) formulations of corticosteroid/cyclodextrin inclusion complexes. European Journal of Pharmaceutics and Biopharmaceutics. 2009;73(1):121-9. DOI: $10.1016 /$ j.ejpb.2009.05.002

14. Shakeel F, Haq N, Alanazi FK, Alsarra IA. Polymeric solid self-nanoemulsifying drug delivery system of glibenclamide using coffee husk as a low cost biosorbent. Powder Technology. 2014;256:352-60.DOI: 10.1016/j.powtec.2014.02.028

15. Bachhav YG, Patravale VB. SMEDDS of Glyburide: Formulation, In Vitro Evaluation, and Stability Studies. AAPS PharmSciTech. 2009;10(2):482-7.DOI: 10.1208/s12249009-9234-1

16. Anonymous. Farmakope Indonesia. IV. Jakarta: Ministry of Health Republic of Indonesia; 1995.

17. United States Pharmacopeial Convention. U.S. Pharmacopeia National Formulary. Rockville, USA: United States Pharmacopeial; 2014. (621) 1-7 (1225) 1-5. (USP 37 NF 32).

18. Anonymous. Farmakope Indonesia. V. Jakarta: Ministry of Health Republic of Indonesia; 2014.

19. Zaman MK, Arayne MS, Sultana N, FAROOQ A. Synthesis and characterization of glibenclamide complexes of magnesium, chromium, cobalt, nickel, zinc and cadmium salts. Pakistan Journal of Pharmeutical Sciences. 2006;19(2):114-118. PMID: 16751121

20. Roy A, Saha S, Roy MN. Exploration of inclusion complexes of probenecid with $\alpha$ and $\beta$-cyclodextrins: Enhancing the utility of the drug. Journal of Molecular Structure. 2017;1144:103-11. DOI:10.1016/j.molstruc.2017.05.002

21. Barman BK, Barman S, Roy MN. Inclusion complexation between tetrabutylphosphonium methanesulfonate as guest and $\alpha$ - and $\beta$-cyclodextrin as hosts investigated by physicochemical methodology. Journal Molecular Liquids. 2018;264:80-7. DOI: 10.1016/j.molliq.2018.04.148

22. Dou S, Ouyang Q, You K, Qian J, Tao N. An inclusion complex of thymol into $\beta$-cyclodextrin and its antifungal activity against Geotrichum citri-aurantii. Postharvest Biology and Technology. 2018;138:31-6.DOI : 10.1016/j.postharvbio.2017.12.011

23. Desai S, Poddar A, Sawant K. Formulation of cyclodextrin inclusion complex-based 
orally disintegrating tablet of eslicarbazepine acetate for improved oral bioavailability. Material Science and Engineering C. 2016;58:826-34.DOI: 10.1016/j. msec.2015.09.019

24. Goodwin DJ, van den Ban S, Denham M, Barylski I. Real time release testing of tablet content and content uniformity. International Journal of Pharmaceutics. 2018 ;537(1-2):183-92.DOI: 10.1016/j. ijpharm.2017.12.011

25. Anonim. British Pharmacopeia. United Kingdom: The Stationery Office; 2625$2626 \mathrm{p}$. 